viability induced by $\mathrm{miR}-1 \quad(\mathrm{n}=6, \mathrm{p}<0.05, \mathrm{n}=9-10$ cells/group, $p<0.05$ and $n=6, p<0.05)$ under oxidative stress. This effect was abolished by insulin.

Conclusions Our findings suggest that miR-1expression is sensitive to $\mathrm{H}_{2} \mathrm{O}_{2}$ stimulation. In addition, insulin decreases miR-1 expression and induces a marked protective effect on miR-1-induced injury under oxidative stress, which may be mediated by the Aktmediated pathway. These results provide an important, novel clue as to the mechanism of the cardiovascular action of insulin.

\section{GW23-e1470 INSULIN AMELIORATES MIR-1-INDUCED INJURY IN H9C2 CELLS UNDER OXIDATIVE STRESS VIA AKT ACTIVATION}

doi:10.1136/heartjnl-2012-302920a.43
Tao Chen, Zuyi Yuan. Department of Cardiovascular Medicine, First Affiliated Hospital of Medical School, Xi'an Jiaotong University

Objectives Growing evidence indicates that aberrant up-regulation of microRNA-1 (miR-1) occurs in ischaemic myocardium. In addition, insulin elicits metabolism-independent cardioprotection against cardiovascular diseases. The aim of this study was to determine whether insulin could ameliorate miR-1-induced injury in $\mathrm{H} 9 \mathrm{c} 2$ cells under oxidative stress and to investigate the underlying mechanisms.

Methods $\mathrm{H} 9 \mathrm{c} 2$ cells were treated by hydrogen peroxide $\left(\mathrm{H}_{2} \mathrm{O}_{2}\right)$. The expression level of miR-1 was detected by quantitative realtime PCR (qRT-PCR). Ad-GFP and Ad-miR-1 were transfected into $\mathrm{H} 9 \mathrm{c} 2$ cells. MiR-1 transfected $\mathrm{H} 9 \mathrm{c} 2$ cells were preincubated with LY294002 $(10 \mu \mathrm{M})$, insulin (100 nM) alone or in combination for $1 \mathrm{hr}$ and subsequently were exposed to $200 \mu \mathrm{M} \mathrm{H}_{2} \mathrm{O}_{2}$. The cell viability, p-Akt/Total-Akt, and ROS production were detected by MTT, western-blot and DHE, respectively.

Results We show that miR-1 is upregulated in $\mathrm{H} 9 \mathrm{c} 2$ cells after treatment with $\mathrm{H}_{2} \mathrm{O}_{2}$, and this effect is both dose- and timedependent. Furthermore, expression of miR-1 decreased significantly after insulin treatment $(4.5 \pm 0.1$ vs $3.0 \pm 0.2, p<0.05)$. To determine the potential role of miR-1 in cellular injury and gene regulation, adenovirus-mediated overexpression of miR-1 was used. Overexpression of miR-1 decreased cell viability by $28 \pm 2 \% \quad(n=6$, $\mathrm{p}<0.05$ ) and damaged Akt activation with or without $\mathrm{H}_{2} \mathrm{O}_{2}$ treatment. To further investigate the effect of the phosphatidylinositol 3-kinase (PI3K)/Akt pathway in miR-1-induced injury, H9c2 cells were pretreated with LY294002 (10 $\mu$ M LY, a specific inhibitor of PI3K) with or without insulin $(100 \mathrm{nM})$ and subjected to $\mathrm{H}_{2} \mathrm{O}_{2}$ treatment. LY pretreatment inhibited Akt activation, lead to increased reactive oxygen species (ROS), and further decreased cell 